\title{
OPTIMASI SUHU DAN WAKTU PEMANASAN TERHADAP PROFIL WARNA MINUMAN SARI TEBU
}

\section{Optimizing of Pasteurization Time and Temperature on Color Profile of Sugarcane Juice Drink}

\author{
Riyadlul Akbar. H. ANR*, Erni Sofia Murtini \\ Jurusan Teknologi Hasil Pertanan, FTP Universitas Brawijaya Malang \\ Jl. Veteran, Malang 66145 \\ *Penulis korespondensi, email: riohidayah95@gmail.com
}

\begin{abstract}
ABSTRAK
Sari tebu memiliki kandungan sukrosa dan membuatnya mudah mengalami kerusakan akibat aktivitas mikroorganisme, sehingga perlu dilakukan proses pengolahan dengan pemanasan. Di sisi lain, sari tebu juga dapat mengalami kerusakan akibat proses pengolahan yaitu reaksi pencoklatan non enzimatis (karamelisasi), sehingga perlu dilakukan optimasi pada proses pemanasan dengan Response Surface Methodology. Penelitian bertujuan untuk mengetahui suhu dan waktu yang optimum pada proses pemanasan sehingga didapat sari tebu dengan profil warna yang optimum sehingga didapatkan suhu dan waktu pemanasan yang optimal untuk mencegah kerusakan akibat aktivitas mikroorganisme dan kerusakan akibat proses pengolahan. Hasil optimasi yang didapat pada proses pemanasan sari tebu yaitu pada suhu pemanasan $85^{\circ} \mathrm{C}$ dan waktu pemanasan 1 menit. Sari tebu dengan perlakuan optimum mempunyai total sukrosa sebesar $12.86 \%$; kadar air sebesar $87.13 \%$; \% brix sebesar 12.87\%; gula reduksi sebesar $1.53 \%$ dan Total Plate Count sebesar $8.53 \times 10^{6} \mathrm{koloni} / \mathrm{ml}$.
\end{abstract}

Kata Kunci: Karamelisasi, Metode Respon Permukaan, Sari Tebu.

\section{ABSTRACT}

Sugar cane juice has a high sucrose content and makes it susceptible to damage due to microorganism activity, so it needs to be processed by heating. On the other hand, sugar cane juice can also damaged due to processing, namely non-enzymatic browning reactions (caramelization), so it is necessary to optimize the heating process with Response Surface Methodology. The heating process carried out needs to be optimized to get the optimal temperature and heating time to prevent damage due to microorganism activity and damage due to processing. Optimization results obtained in the process of heating sugar cane juice is at $85^{\circ} \mathrm{C}$ heating temperature and heating time of 1 minute. Sugar cane juice with optimum treatment has a total sucrose of $12.86 \%$; moisture content of $87.13 \%$; \% brix of $12.87 \%$; reduction sugar of $1.53 \%$ and total plate count of $8.53 \times 106$ colonies $/ \mathrm{ml}$.

Keywords: Caramelization, Responses Surface Methodology, Sugarcane Juice

\section{PENDAHULUAN}

Produk sari tebu kaya akan nutrisi mengandung sekitar $15-18 \%$ sukrosa, $0.5 \%$ gula pereduksi, sejumlah senyawa nitrogen dan beberapa unsur mineral untuk pertumbuhan mikroba, sehingga perlu dilakukan proses pengolahan lebih lanjut untuk mencegahnya dari kerusakan (Singh, 2006). Banyaknya jumlah nutrisi yang terdapat pada produk sari tebu membuat produk tersebut mudah mengalami kerusakan, sehingga perlu dilakukan proses pengolahan untuk mencegah terjadinya kerusakan. Di sisi lain, sari tebu juga dapat mengalami kerusakan akibat proses pengolahan yaitu reaksi pencoklatan non enzimatis (karamelisasi). Terjadinya reaksi karamelisasi pada sari tebu selama proses pemanasan 
berpengaruh langsung terhadap kenampakan warna pada sari tebu secara fisik. Hal tersebut juga dapat merusak komponen sukrosa pada sari tebu, sehingga perlu dilakukan optimasi pada proses pemanasan sari tebu.

Penelitian ini dilakukan dengan melakukan pengolahan pada produk sari tebu yang didapatkan. Proses pengolahan yang paling mungkin digunakan pada produk sari tebu adalah proses pengolahan dengan panas. Proses ini dipilih karena terdapat enzim invertase dan mikroba yang hanya dapat dihentikan aktivitasnya dengan pemanasan (Solomon, 2009). Faktor-faktor yang pengolahan paling berpengaruh terhadap mutu dari sari tebu adalah suhu dan waktu pemanasan, sehingga dipilihlah faktor suhu dan waktu pemanasan sebagai perlakuan utama pada penelitian ini. Fokus kajian pada penelitian ini mencari titik optimal pada proses pemanasan sari tebu dari beberapa kombinasi perlakuan suhu dan waktu pemanasan untuk menghasilkan sari tebu dengan kualitas terbaik.

\section{BAHAN DAN METODE}

\section{Bahan}

Bahan baku untuk pembuatan sari tebu berupa batang tebu hijau (Saccarum officinarum) varietas PSJK 922 yang diambil dari lahan tebu milik petani tebu dengan usia tanam 1 tahun yang di Krebet, Malang, Jawa Timur. Bahan yang digunakan untuk analisis kimia yaitu Larutan Luff Schoorl, larutan Nelson Somogyi, larutan $\mathrm{Na}_{2} \mathrm{~S}_{2} \mathrm{O}_{3}$, (Na-thiosulfat) $0.1 \mathrm{~N}$, larutan $\mathrm{H}_{2} \mathrm{SO}_{4} 20 \%$, indicator amilum $1 \%$, larutan $\mathrm{KI} 20 \%$, larutan $\mathrm{HCl} 4 \mathrm{~N}$, larutan $\mathrm{NaOH} 50 \%$, indikator PP dan aquades. Bahan yang digunakan untuk analisis mikroba adalah media plate count agar (PCA), larutan pepton, aquades dan etanol $70 \%$.

\section{Alat}

Alat yang digunakan untuk pembuatan minuman sari tebu adalah alat penggiling tebu, filter, cane cleaner, spectrophotometer, kuvet, kompor, panci, botol polyethylene terephthalate (PET). Alat untuk analisis adalah labu ukur $100 \mathrm{ml}$, stop Erlenmeyer $250 \mathrm{ml}$, pendingin balik, bunsen, buret $50 \mathrm{ml}$, timbangan analitik, kaki tiga dan kawat kasa, pipet volume $25 \mathrm{ml}$, beaker glass $250 \mathrm{ml}$, water bath dan termometer. Alat yang digunakan untuk analisis mikroba perlakuan pada terbaik yaitu autoclave listrik, $\mathrm{pH}$ meter, sarung tangan plastik, spatula atau sendok, plastik steril, cawan petri, volume pipet, tabung reaksi, inkubator, colony counter, botol schoot duran, timbangan digital, dan laminar air flow.

\section{Desain Penelitian}

Penelitian ini menggunakan metode respon permukaan (Response Surface Method) dengan rancangan desain dua faktor dengan model Central Composite Design. Respon yang diamati adalah perubahan warna pada sari tebu (R1) yang dipengaruhi oleh 2 faktor, yaitu suhu (X1) dan waktu pemanasan (X2). Dalam penelitian ini suhu yang ingin diteliti yaitu dengan interval $90 \pm 5^{\circ} \mathrm{C}$ dan waktu pemanasan dengan interval $3 \pm 2$ menit. Dilakukan dua tahap percobaan dalam metode permukaan respons, yaitu percobaan orde I dan percobaan orde II. Percobaan orde I, memerlukan rancangan percobaan yang terdiri dari rancangan faktorial $2^{\mathrm{k}}$ dan rancangan titik pusat. Kemudian rancangan percobaan tersebut dimasukan dalam aplikasi Design Expert versi 10. Percobaan ini menggunakan 4 Center Point dengan CCD Option menggunakan model face centered dan dihasilkan 12 run percobaan dengan center point pada suhu pemanasan $90^{\circ} \mathrm{C}$ dan waktu pemanasan 3 menit.

\section{Tahapan Penelitian}

Penelitian dilakukan dengan 2 tahapan. Tahap pertama adalah pembuatan bahan baku sari tebu dan tahapan kedua adalah pemanasan sari tebu. Tahapan proses pembuatan sari tebu dilakukan berdasarkan penelitian yang dilakukan oleh Andrade et al (2014) dengan beberapa proses, diantaranya adalah penebangan batang tebu, pembersihan batang tebu, pemotongan batang tebu dan ekstraksi sari tebu dengan cara penggilingan. Tahapan selanjutnya adalah pemanasan pada sari tebu dengan suhu dan waktu pemanasan yang sesuai dengan yang didapatkan pada desain percobaan dari aplikasi Design Expert. 


\section{Prosedur Analisis}

Analisis yang dilakukan pada penelitian ini meliputi analisis pada bahan baku dan analisis pada produk sari tebu dengan perlakuan optimum. Analisis yang dilakukan pada bahan baku adalah analisis \%brix, kadar sukrosa, kadar gula reduksi dan jumlah mikroba (Total Plate Count). Analisis pada sari tebu dengan perlakuan optimum adalah \%brix (refraktometer), kadar sukrosa (metode Luff Schoorl), kadar gula reduksi (metode Luff Schoorl) dan jumlah mikroba (Total Plate Count) (Modifikasi dari Yunita, 2016).

\section{HASIL DAN PEMBAHASAN}

\section{Analisis Bahan Baku}

Bahan baku yang digunakan pada pembuatan sari dalam penelitian ini adalah batang tebu dengan varietas PSJK 922 dengan umur tanaman 8-12 bulan. Analisis pada bahan baku sari tebu yang didapat antara lain analisis \%brix, kadar sukrosa, kadar gula reduksi, jumlah mikroba (total plate count) dan profil warna (L, a dan b). Berikut hasil analisis bahan baku ditampilkan pada Tabel 1.

Tabel 1. Karakteristik Kimia Sari Tebu

\begin{tabular}{|c|c|c|}
\hline \multirow{2}{*}{ Komponen } & \multicolumn{2}{|c|}{ Sari Tebu } \\
\hline & Hasil Analisis & Literatur \\
\hline Kadar Gula Reduksi (\%) & $0.63 \pm 0,31$ & $0.5^{\mathrm{b}}$ \\
\hline Total Sukrosa (\%) & $11.23 \pm 0,45$ & $12.90^{c}$ \\
\hline Brix (\%) & $11.73 \pm 0,49$ & $15.12^{d}$ \\
\hline Total Plate Count (cfu/ml) & $12.3 \times 10^{6} \pm 0,89$ & $4.56 \times 10^{6(b)}$ \\
\hline Warna L & $27.93 \pm 0,21$ & - \\
\hline Warna a & $-2.03 \pm 0,15$ & - \\
\hline Warna b & $4.53 \pm 0,40$ & - \\
\hline
\end{tabular}

Keterangan: 1 . Setiap data yang didapat merupakan rerata dari 3 kali ulangan \pm standar deviasi

a Swaminathan, 1991

${ }^{b}$ Sankhla, S. (2011)

c USDA (2018)

${ }^{d}$ Kuspratomo et al. (2012)

Tabel 1 menampilkan hasil analisis bahan baku dan perbandingannya dengan beberapa literatur. Hasil analisis bahan baku yang didapat pada semua parameter menunjukkan nilai yang berbeda dengan yang ada pada literatur. Perbedaan tersebut disebabkan oleh beberapa faktor yang secara langsung memengaruhi hasil analisis. Faktorfaktor tersebut antara lain perbedaan varietas tebu yang digunakan pada proses pembuatan sari tebu (Irawan et al., 2015), metode analisis yang digunakan (Kuspratomo, 2012), tingkat kematangan batang tebu dan kondisi fisik batang tebu (Sunantyo, 2012).

\section{Optimasi Suhu dan Waktu Pemanasan Terhadap Profil Warna Sari Tebu}

Hasil analisis hubungan antara suhu dan waktu pemanasan terhadap profil warna minuman sari tebu dari 12 perlakuan ditampilkan pada Tabel 2. Tabel 2 menunjukkan peningkatan nilai respon profil warna $L$ pada minuman sari tebu terendah dihasilkan pada suhu pemanasan $85^{\circ} \mathrm{C}$ dan waktu pemanasan 1 menit. Sedangkan peningkatan nilai profil warna $L$ tertinggi didapatkan pada suhu pemanasan $95^{\circ} \mathrm{Cdan}$ waktu pemanasan 5 menit. Hal yang sama juga terjadi pada peningkatan nilai pada profil warna a dan profil warna $b$. Perubahan nilai profil warna a dan b terendah didapat pada suhu pemanasan $85^{\circ} \mathrm{C}$ dan waktu pemanasan 1 menit sedangkan perubahan tertinggi didapatkan pada suhu pemanasan $95^{\circ} \mathrm{C}$ dan waktu pemanasan 5 menit. 
Table 2. Hasil Analisis Respon Suhu dan Waktu Pemanasan terhadap Profil Warna Minuman Sari Tebu

\begin{tabular}{ccccccc}
\hline \multirow{2}{*}{ Std } & \multirow{2}{*}{ Run } & Suhu $\left({ }^{\circ} \mathbf{C}\right)$ & \multirow{2}{*}{ Waktu } & \multicolumn{3}{c}{ Respon } \\
\cline { 5 - 7 } & & & & Warna L & Warna a & Warna b \\
\hline 1 & 3 & 85 & 1 & 28.37 & -2.13 & 4.57 \\
2 & 12 & 95 & 1 & 30.93 & -2.53 & 5.23 \\
3 & 7 & 85 & 5 & 30.40 & -2.53 & 5.20 \\
4 & 2 & 95 & 5 & 33.97 & -3.53 & 6.60 \\
5 & 8 & 85 & 3 & 29.27 & -2.43 & 4.67 \\
6 & 10 & 95 & 3 & 32.57 & -3.03 & 5.93 \\
7 & 6 & 90 & 1 & 29.60 & -2.30 & 4.83 \\
8 & 4 & 90 & 5 & 31.63 & -2.77 & 5.37 \\
9 & 9 & 90 & 3 & 31.00 & -2.60 & 5.13 \\
10 & 5 & 90 & 3 & 31.15 & -2.67 & 5.13 \\
11 & 11 & 90 & 3 & 30.95 & -2.63 & 5.30 \\
12 & 1 & 90 & 3 & 30.97 & -2.60 & 5.00 \\
\hline
\end{tabular}

\section{Respon Warna L}

Prediksi model $2 F I$ vs Linear disarankan oleh program Design Expert untuk menjelaskan hubungan antara suhu dan waktu pemanasan terhadap respon warna $L$ pada minuman sari tebu. model tersebut dipilih berdasarkan pada tiga metode evaluasi kualitas model yaitu analisis jumlah kuadrat dari urutan model (Sequential Model Sum of Squares), pengujian ketidak tepatan (Lack of Fit) dan ringkasan model statistik (Summary of Statistic). Hasil analisis ragam (ANOVA) respon warna $L$ dari program Design Expert ditunjukkan pada Tabel 3.

Table 3. Tabel ANOVA untuk model 2FI vs Linear (Respon Warna L)

\begin{tabular}{lllllll}
\hline $\begin{array}{c}\text { Sumber } \\
\text { Keragaman }\end{array}$ & $\begin{array}{c}\text { Jumlah } \\
\text { Kuadrat }\end{array}$ & $\begin{array}{c}\text { Derajat } \\
\text { bebas }\end{array}$ & $\begin{array}{c}\text { Kuadrat } \\
\text { tengah }\end{array}$ & F hitung & $\begin{array}{c}\text { P-Value } \\
\text { (Prob>F) }\end{array}$ & Keterangan \\
\hline Model & 23.48 & 3 & 7.83 & 180.02 & $<0.0001$ & Significant \\
A-suhu & 14.82 & 1 & 14.82 & 340.92 & $<0.0001$ & \\
$B$-waktu & 8.40 & 1 & 8.40 & 193.26 & $<0.0001$ & \\
AB & 0.26 & 1 & 0.26 & 5.87 & 0.0417 & \\
Residual & 0.35 & 8 & 0.043 & & & \\
Lack of Fit & 0.32 & 5 & 0.065 & 7.86 & 0.0601 & Not significant \\
Pure Error & 0.025 & 3 & $8.225 E-003$ & & & \\
Cor Total & 23.83 & 11 & & & & \\
\hline
\end{tabular}

Variable suhu dan waktu memberi pengaruh yang nyata terhadap respon warna $\mathrm{L}$ pada minuman sari tebu. Hal tersebut ditunjukkan dengan nilai dari $p$-value kurang dari $5 \%$ $(p<0.05)$ masing-masing yaitu sebesar $<0.0001 \quad(<0.01 \%)$. Selain itu, variable suhu dan waktu (kuadrat) juga memberikan pengaruh yang nyata terhadap respon Warna L. berdasarkan hasil analisis ragam (ANOVA) pada respon warna $L$ model $2 F I$ vs Linear didapatkan persamaan model yang diberikan oleh Design Expert 10.0.0. Persamaan berikut merupakan persamaan terkode dan aktual yang diberikan oleh Design Expert 10.0.0 dari model yang terpilih terhadap respon yang dihasilkan:

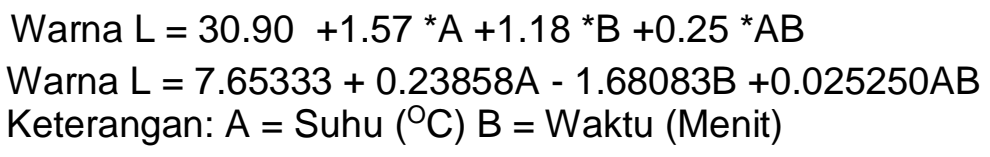


Gambar 1 merupakan kurva hubungan antara suhu dan waktu pemanasan terhadap respon warna $\mathrm{L}$. Berdasarkan data yang ditampilkan pada kurva diatas, terjadi peningkatan nilai warna $\mathrm{L}$ dari suhu $85^{\circ} \mathrm{C}$ hingga $95^{\circ} \mathrm{C}$ dan waktu 1 hingga 5 menit. Nilai $\mathrm{L}$ pada pengukuran profil warna menunjukkan tingkat kecerahan suatu produk. Nilai $L$ yang rendah menunjukkan warna produk tersebut cerah sedangkan jika nilai $L$ produk tinggi maka warna produk tersebut akan gelap. Hal tersebut juga terjadi pada produk minuman sari tebu.

Pada proses pengolahan bahan yang memiliki kandungan gula yang tinggi seperti minuman sari tebu, suhu dan waktu pemanasan mempunyai pengaruh yang nyata terhadap perubahan profil warna. Perubahan warna yang terjadi pada produk diduga disebabkan oleh terjadinya degradasi pigmen klorofil. Klorofil merupakan pigmen utama pada sari tebu yang kandungannya sebesar $1 \mathrm{mg} / 100 \mathrm{ml}$ (Yusof et al., 2000). Keberadaan klorofil sebagai pigmen utama pada sari tebu inilah yang menyebabkan sari tebu memiliki warna hijau dan memungkinkan untuk ikut berperan terhadap terjadinya degredasi warna. Terjadinya degradasi pigmen klorofil disebabkan karena klorofil merupakan pigmen warna yang sangat peka terhadap cahaya, suhu, dan juga pH (Sivorsky, 2007). Degradasi ini diduga disebabkan oleh reaksi feofitinasi yaitu reaksi pembentukan pheophytin yang merupakan bentuk klorofil yang telah kehilangan ion $\mathrm{mg}^{2+}$.
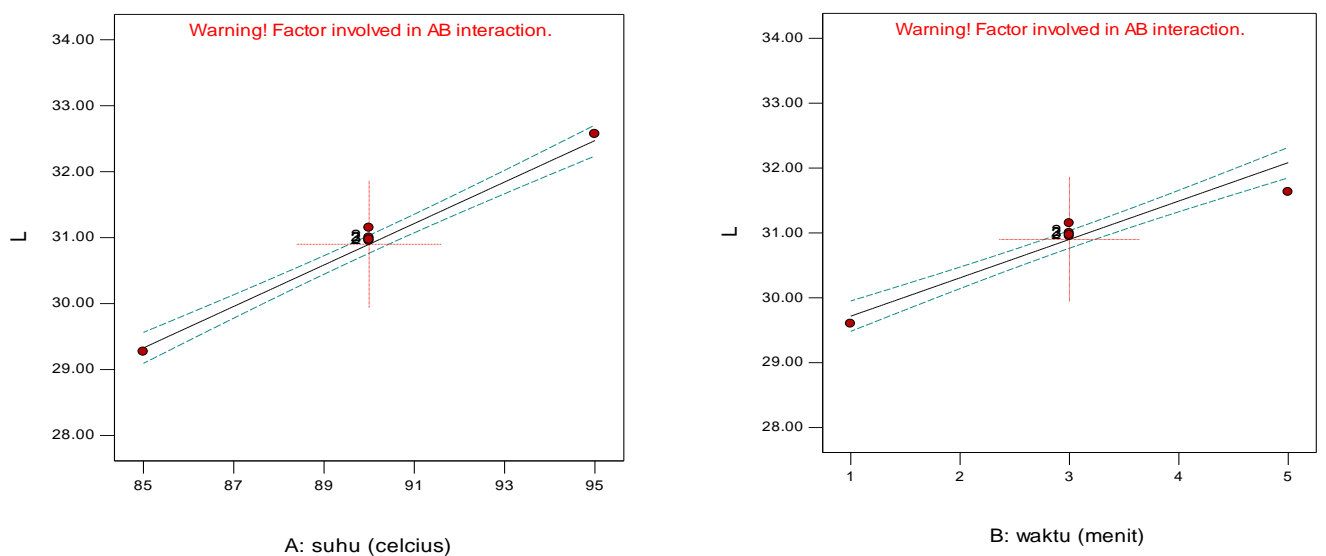

Gambar 1. Kurva Permukaan Respon Variabel Suhu dan Waktu Pemanasan terhadap Respon Warna L

\section{Respon Warna a}

Prediksi model kuadratik disarankan oleh program Design Expert untuk menjelaskan hubungan antara suhu dan waktu pemanasan terhadap respon warna a pada minuman sari tebu. model tersebut dipilih berdasarkan pada tiga metode evaluasi kualitas model yaitu analisis jumlah kuadrat dari urutan model (Sequential Model Sum of Squares), pengujian ketidak tepatan (Lack of Fit) dan ringkasan model statistik (Summary of Statistic). Hasil analisis ragam (ANOVA) respon warna $\mathrm{L}$ dari program Design Expert ditunjukkan pada Tabel 4.

Variable suhu dan waktu memberi pengaruh yang nyata terhadap respon warna a pada minuman sari tebu. Hal tersebut ditunjukkan dengan nilai dari $p$-value kurang dari $5 \%$ $(p<0.05)$ masing-masing yaitu sebesar $<0.0001(<0.01 \%)$. Selain itu, variable suhu dan waktu (kuadrat) juga memberikan pengaruh yang nyata terhadap respon Warna a. Berdasarkan hasil analisis ragam (ANOVA) pada respon warna a model kuadratik didapatkan persamaan model yang diberikan oleh Design Expert 10.0.0. Persamaan berikut merupakan persamaan terkode dan aktual yang diberikan oleh Design Expert 10.0.0 dari model yang terpilih terhadap respon yang dihasilkan :

$$
\begin{aligned}
& \text { Warna } a=-2.62-0.33 * A-0.31 * B-0.15 * A B-0.13 * A^{2}+0.070 * B^{2} \\
& \text { Warna } a=-40.4+0.87 A+1.08 B-0.015 A B--5.0000010 E-003 A^{2}+0.017 B^{2} \\
& \text { Keterangan: } A=\text { Suhu }\left({ }^{\circ} \mathrm{C}\right) B=\text { Waktu (Menit) }
\end{aligned}
$$


Table 4. Tabel ANOVA untuk Model Kuadratik (Respon Warna a)

\begin{tabular}{|c|c|c|c|c|c|c|}
\hline $\begin{array}{c}\text { Sumber } \\
\text { Keragaman }\end{array}$ & $\begin{array}{l}\text { Jumlah } \\
\text { Kuadrat }\end{array}$ & $\begin{array}{l}\text { Derajat } \\
\text { bebas }\end{array}$ & $\begin{array}{c}\text { Kuadrat } \\
\text { tengah }\end{array}$ & $\begin{array}{c}\mathbf{F} \\
\text { hitung }\end{array}$ & $\begin{array}{c}\text { P-Value } \\
\text { (Prob }>\text { F) }\end{array}$ & Keterangan \\
\hline Model & 1.38 & 5 & 0.28 & 65.54 & $<0.0001$ & significant \\
\hline A-suhu & 0.67 & 1 & 0.67 & 157.89 & $<0.0001$ & \\
\hline B-waktu & 0.58 & 1 & 0.58 & 138.04 & $<0.0001$ & \\
\hline$A B$ & 0.090 & 1 & 0.090 & 21.32 & 0.0036 & \\
\hline$A^{2}$ & 0.042 & 1 & 0.042 & 9.87 & 0.0200 & \\
\hline $\mathrm{B}^{2}$ & 0.013 & 1 & 0.013 & 3.09 & 0.1290 & \\
\hline Residual & 0.025 & 6 & 4.222E-003 & & & \\
\hline Lack of Fit & 0.022 & 3 & 7.344E-003 & 6.68 & 0.0766 & not significant \\
\hline Pure Error & 3.300E-003 & 3 & 1.100E-003 & & & \\
\hline Cor Total & 1.41 & 11 & & & & \\
\hline
\end{tabular}

Gambar 2 merupakan kurva hubungan antara suhu dan waktu pemanasan terhadap respon warna a. Berdasarkan data yang ditampilkan pada kurva diatas, terjadi penurunan nilai warna a dari suhu $85^{\circ} \mathrm{C}$ hingga $95^{\circ} \mathrm{C}$ dan waktu 1 hingga 5 menit. Nilai a pada pengukuran profil warna menunjukkan tingkat kehijauan dan kemerahan warna suatu produk. Nilai positif (+) untuk menunjukkan tingkat intensitas warna merah dan nilai negative (-) untuk menunjukkan tingkat intesitas warna hijau. Hasil dari pengamatan didapatkan skala warna $b$ pada sari tebu menunjukkan nilai negatif. Nilai negatif yang diperoleh pada sari tebu terus mengalami penurunan dengan semakin bertambahnya suhu dan waktu pemanasan. Hal tersebut menunjukkan bahwa sari tebu akan semakin hijau dengan semakin bertambahnya suhu dan waktu pemanasan.

Peningkatan intensitas warna hijau tersebut mempunyai hubungan dengan penurunan intensitas kecerahan. Hal tersebut terjadi karena reaksi karamelisasi (pencoklatan non enzimatis). Pencoklatan non enzimatis terjadi pada suhu yang tinggi dan menyebabkan molekul sukrosa mengalami inversi. Inversi inilah yang menyebabkan terjadinya pencoklatan dan memengaruhi warna sari tebu.
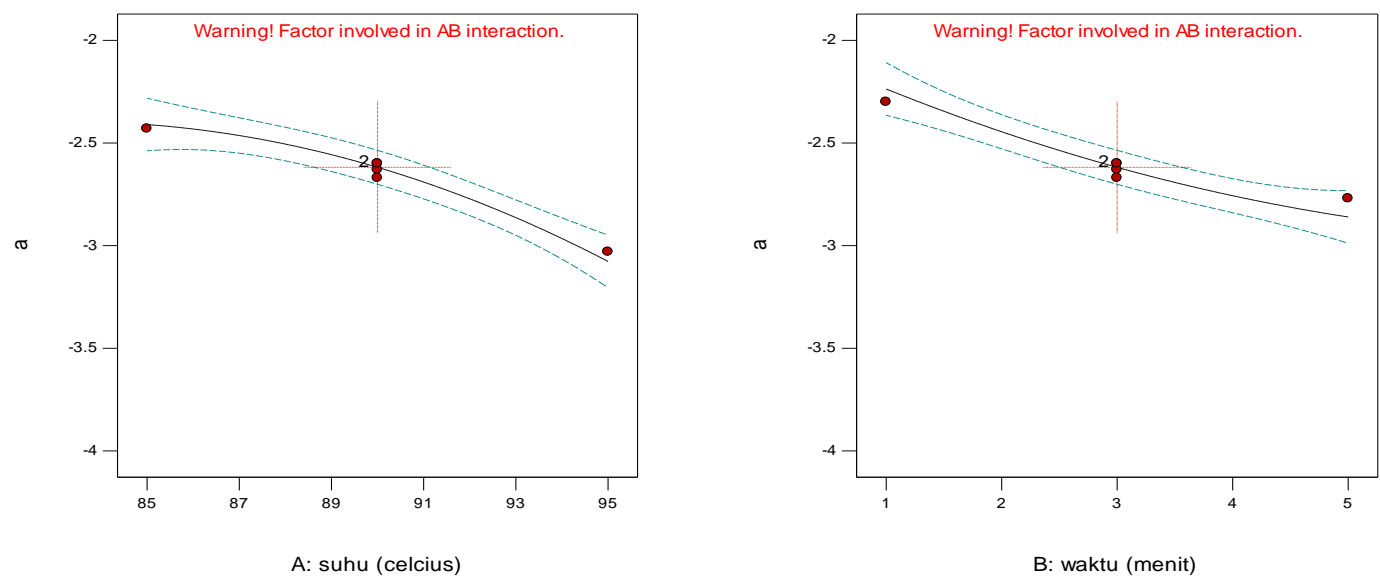

Gambar 2. Kurva Permukaan Respon Variabel Suhu dan Waktu Pemanasan terhadap Respon Warna a

\section{Respon Warna b}

Prediksi model linier disarankan oleh program Design Expert untuk menjelaskan hubungan antara suhu dan waktu pemanasan terhadap respon warna $b$ pada minuman sari tebu. Model tersebut dipilih berdasarkan pada tiga metode evaluasi kualitas model yaitu 
analisis jumlah kuadrat dari urutan model (Sequential Model Sum of Squares), pengujian ketidak tepatan (Lack of Fit) dan ringkasan model statistik (Summary of Statistic). Hasil analisis ragam (ANOVA) respon warna $L$ dari program Design Expert ditunjukkan pada Tabel 4.

Table 5. Tabel ANOVA untuk model kuadratik (Respon Warna b)

\begin{tabular}{lllllll}
\hline $\begin{array}{c}\text { Sumber } \\
\text { Keragaman }\end{array}$ & $\begin{array}{c}\text { Jumlah } \\
\text { Kuadrat }\end{array}$ & $\begin{array}{c}\text { Derajat } \\
\text { bebas }\end{array}$ & $\begin{array}{c}\text { Kuadrat } \\
\text { tengah }\end{array}$ & F hitung & $\begin{array}{c}P \text {-Value } \\
\text { (Prob }>\text { F) }\end{array}$ & Keterangan \\
\hline Model & 2.91 & 2 & 1.46 & 28.57 & 0.0001 & significant \\
A-suhu & 1.84 & 1 & 1.84 & 36.04 & 0.0002 & \\
$B$-waktu & 1.08 & 1 & 1.08 & 21.10 & 0.0013 & \\
Residual & 0.46 & 9 & 0.051 & & & \\
Lack of Fit & 0.41 & 6 & 0.069 & 4.55 & 0.1206 & Not significant \\
Pure Error & 0.045 & 3 & 0.015 & & & \\
Cor Total & 3.37 & 11 & & & & \\
\hline
\end{tabular}

Model linier memberikan pengaruh yang nyata terhadap respon warna $\mathrm{b}$, dengan nilai $p$-value sebesar $0.0001(0.01 \%)$. Nilai tersebut lebih kecil dari $5 \%(p$-value $<0.05)$. Variable suhu dan waktu juga memberi pengaruh yang nyata terhadap respon warna b pada minuman sari tebu. Hal tersebut ditunjukkan dengan nilai dari $p$-value kurang dari $5 \%(p<0,05)$ masingmasing yaitu sebesar 0.0002 dan 0.0013 . Berdasarkan hasil analisis ragam (ANOVA) pada respon warna $L$ model $2 F I$ vs Linear didapatkan persamaan model yang diberikan oleh Design Expert 10.0.0. Persamaan berikut merupakan persamaan terkode dan aktual yang diberikan oleh Design Expert 10.0.0 dari model yang terpilih terhadap respon yang dihasilkan :

Warna $b=+5.25+0.55$ * $A+0.42$ * $B$

Warna $b=-5.34833+0.11067 A++0.21167 B$

Keterangan: $\mathrm{A}=$ Suhu $\left({ }^{\circ} \mathrm{C}\right) \mathrm{B}=$ Waktu (Menit)
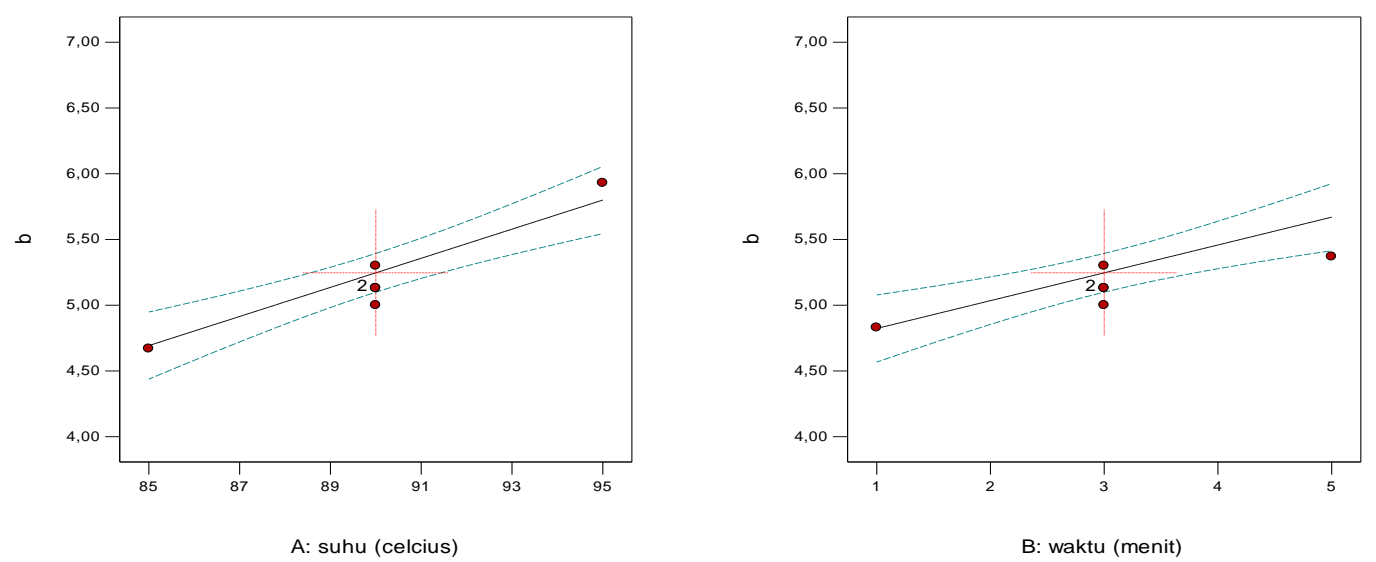

Gambar 3 Kurva Permukaan Respon Variabel Suhu dan Waktu Pemanasan terhadap Respon Warna b

Gambar 3 merupakan kurva hubungan antara suhu dan waktu pemanasan terhadap respon warna b. Berdasarkan data yang ditampilkan pada kurva diatas, terjadi peningkatan nilai warna b dari suhu $85^{\circ} \mathrm{C}$ hingga $95^{\circ} \mathrm{C}$ dan waktu 1 hingga 5 menit. Nilai b pada pengukuran profil warna menunjukkan tingkat kekuningan dan kehijauan warna suatu produk. Nilai positif $(+)$ untuk menunjukkan tingkat intensitas warna kuning dan nilai negative (-) untuk menunjukkan tingkat intesitas warna biru. Hasil dari pengamatan didapatkan skala warna $b$ pada sari tebu menunjukkan nilai negatif. Nilai negatif yang diperoleh pada sari tebu terus mengalami penurunan dengan semakin bertambahnya suhu dan waktu pemanasan. Hal 
tersebut menunjukkan bahwa sari tebu akan semakin kuning dengan semakin bertambahnya suhu dan waktu pemanasan

\section{Penentuan Titik Optimum Perlakuan}

Penentuan titik optimum dilakukan dengan melakukan pengaturan secara numerik di menu Optimization pada aplikasi Design Expert 10. Pilihan yang tersedia pada aplikasi tersebut digunakan untuk menentukan nilai titik optimum yang akan didapat pada faktor dan respon perlakuan. Penentuan titik optimum perlakuan didapatkan dengan menentukan pengaturan menu goal pada masing-masing respon dan perlakuan.

Goal yang dipilih pada faktor suhu dan waktu pasteurisasi adalah minimize, pada respon warna $L$ dan warna b goal yang dipilih adalah minimize dan respon warna a goal yang dipilih adalah maximize. Goal pada faktor suhu dan waktu pasteurisasi dijadikan minimize agar menjaga produk dari kerusakan karena proses pengolahan akibat lamanya kontak bahan dengan panas. Goal pada respon warna $L$ dan warna b dijadikan minimize dan respon warna a dijadikan maximize bertujuan agar didapat produk dengan sari tebu profil warna yang mendekati warna asli dari bahan baku.

\section{Verifikasi Hasil Optimum}

Verifikasi dilakukan untuk membuktikan solusi hasil optimum yang disarankan oleh Design Expert 10 telah sesuai dengan penelitian yang dilakukan secara aktual. Verifikasi dilakukan dengan cara mencari rentang dari suhu dan waktu pemanasan terendah hingga tertinggi untuk menghasilkan perubahan profil warna optimum. Hasil verifikasi interpretasi dari program dapat dilihat pada Gambar 4.7.

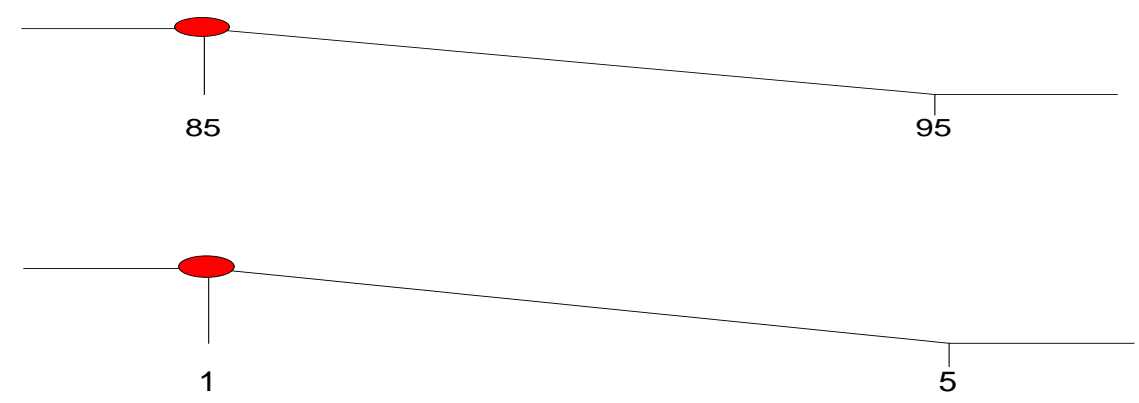

B:waktu $=1$

Gambar 4 Hasil Predikasi Menggunakan Aplikasi Design Expert 10.

Berdasarkan hasil prediksi dari Design Expert 10, dari rentang suhu pemanasan $85^{\circ} \mathrm{C}$ sampai $95^{\circ} \mathrm{C}$ dan rentang waktu pemanasan 1 sampai 5 menit diperoleh suhu $85^{\circ} \mathrm{C}$ dan waktu 1 menit sebagai perlakuan optimum. Perlakuan tersebut menghasilkan nilai pada $\mathrm{L}$ sebesar 28.40 , nilai a sebesar -2.18 dan nilai b sebesar 4.27 dengan desirability sebesar 0.992. Tahapan berikutnya setelah didapatkan perlakuan optimum yang disarankan adalah melakukan verifikasi dengan pengujian secara actual. Hasil verifikasi yang didapat secara aktual kemudian dibandingkan dengan prediksi yang diberikan oleh program. Nilai verifikasi akan diterima jika hasil perbandingan yang dihasilkan kurang dari 5\% (Amalia, 2016). Hasil Verifikasi dan pediksi dapat dilihat pada Tabel 6.

Tabel 6 menunjukkan hasil prediksi dari solusi titik optimum yang disarankan oleh Design Expert 10 yaitu respon warna $L$ sebesar 28.4, warna a sebesar -2.18 dan respon warna $b$ sebesar 4.27. Sedangkan hasil verifikasi yang didapat pada penelitian actual untuk respon warna $L$ sebesar 28.6, respon warna a sebesar -2.24 dan respon warna b sebesar 4.42. Hasil perbandingan selisih dari selisih ketiga respon tersebut lebih kecil dari $5 \%$, artinya nilai verifikasi telah sesuai dengan prediksi program. Perbedaan nilai prediksi yang tidak lebih dari $5 \%$ mengindikasikan bahwa model tersebut telah cukup sesuai untuk proses, dengan 
demikian selisih nilai tidak terlalu signifikan dan solusi variable bebas yang diberikan dapat diterima.

Tabel 6. Perbandingan antara Hasil Prediksi dengan Verifikasi Aktual

\begin{tabular}{lcclll}
\hline & Suhu $\left({ }^{\circ} \mathbf{C}\right)$ & Waktu (menit) & \multicolumn{1}{c}{ Warna L } & \multicolumn{1}{c}{ Warna a } & \multicolumn{1}{c}{ Warna b } \\
\hline Prediksi $^{*}$ & 85 & 1 & 28.4 & -2.18 & 4.27 \\
Aktual $^{* *}$ & 85 & 1 & $28.6 \pm 0,25$ & $-2.24 \pm 0,05$ & $4.42 \pm 0.24$ \\
Selisih Nilai Aktual dan Prediksi & $0.7 \%$ & $2.76 \%$ & $3.52 \%$ \\
\hline
\end{tabular}

Keterangan :

Setiap data merupakan data dari 3 kali ulangan

Angka dibelakang tanda \pm merupakan standar deviasi

*prediksi berdasarkan solusi yang disarankan oleh Design Expert 10

**verifikasi berdasarkan penelitian actual

\section{Karakteristik Sari Tebu dengan Perlakuan Optimum}

Berikut ditampilkan hasil uji t statistik pada data yang didapat dari sari tebu hasil perlakuan optimum dan kontrol pada perlakuan \% brix, kadar gula reduksi dan total plate count (TPC) Tabel 7.

Tabel 7. Hasil Uji T Statistik Hasil Perlakuan Optimum dan Kontrol

\begin{tabular}{|c|c|c|c|c|c|c|c|}
\hline Paremeter & Kondisi & $\begin{array}{c}\text { Ulangan } \\
1\end{array}$ & $\begin{array}{c}\text { Ulangan } \\
\mathbf{2}\end{array}$ & $\begin{array}{c}\text { Ulangan } \\
3\end{array}$ & $\begin{array}{c}\text { Rata- } \\
\text { rata }\end{array}$ & $\begin{array}{c}\mathrm{T}- \\
\text { value }\end{array}$ & $\begin{array}{c}P- \\
\text { value }\end{array}$ \\
\hline \multirow{4}{*}{$\begin{array}{l}\text { Total Sukrosa } \\
(\%) \\
\text { Brix (\%) }\end{array}$} & Optimum & 12.44 & 13.45 & 12.69 & 12.86 & \multirow{2}{*}{3.24} & \multirow{2}{*}{0.084} \\
\hline & Kontrol & 11.15 & 10.83 & 11.71 & 11.23 & & \\
\hline & Optimum & 12.3 & 13.5 & 12.8 & 12.87 & \multirow{2}{*}{6.43} & \multirow[b]{2}{*}{0.023} \\
\hline & Kontrol & 11.5 & 12.3 & 11.4 & 11.73 & & \\
\hline \multirow{4}{*}{$\begin{array}{l}\text { Gula reduksi } \\
(\%) \\
\text { TPC (CFU/ml) }\end{array}$} & Optimum & 1.3 & 1.9 & 1.4 & 1.53 & \multirow{2}{*}{2.50} & \multirow{2}{*}{0.130} \\
\hline & Kontrol & 0.9 & 0.3 & 0.7 & 0.63 & & \\
\hline & Optimum & 8.4 & 7.9 & 9.3 & 8.53 & \multirow{2}{*}{2.22} & \multirow{2}{*}{0.157} \\
\hline & Kontrol & 9.2 & 9.9 & 9.7 & 9.60 & & \\
\hline
\end{tabular}

Tabel 7 menampilkan hasil uji T statistik. Uji statistik t menunjukkan seberapa jauh pengaruh satu variabel independen secara individual dalam menerangkan variasi variabel dependen. Pengujian dilakukan dengan menggunakan significance level $0.05(a=5 \%)$. Jika nilai siginifikansi $p$-value $<0.05$ terdapat perbedaan yang signifikan antara hasil penghitungan \%brix, kadar gula reduksi dan total plate count (TPC) sari tebu perlakuan optimum dengan sari tebu control (tanpa perlakuan). Jika $p$-value $>0.05$, maka tidak terdapat perbedaan yang signifikan antara data sari tebu perlakuan optimum dengan sari tebu control.

Angka $p$-value yang diperoleh pada \%brix sebesar 0.023 . Nilai tersebut lebih kecil dari 0.05 ( $p$-value $<0.05)$ dan nilai tersebut menunjukkan bahwa terdapat perbedaan yang signifikan antara \%brix pada sari tebu perlakuan optimum dengan sari tebu kontrol. Hal tersebut berbeda dengan $p$-value yang didapat pada total sukrosa, kadar gula reduksi dan total plate count (TPC). Nilai $p$-value yang didapat pada total sukrosa, gula reduksi dan total plate count (TPC) masing-masing sebesar $0.084 ; 0.130$ dan 0.157 dan angka tersebut lebih besar dari 0.05 ( $p$-value>0.05). Angka $p$-value yang didapat menunjukkan bahwa tidak terdapat perbedaan yang signifikan pada total sukrosa, kadar gula reduksi dan total plate count (TPC) antara sari tebu perlakuan optimum dengan sari tebu kontrol.

\section{SIMPULAN}

Dalam penelitian ini, didapatkan kesimpulan bahwa suhu dan waktu pemanasan memberikan pengaruh yang nyata terhadap profil warna minuman sari tebu. Pada masingmasing perlakuan didapati perubahan profil warna minuman sari tebu, baik pada warna $L$, 
warna a maupun warna b. Selisih perubahan profil warna paling rendah didapat pada suhu pemanasan $85^{\circ} \mathrm{C}$ dan waktu pemanasan 1 menit. Sedangkan selisih perubahan profil warna paling besar didapat pada suhu pemanasan $95^{\circ} \mathrm{C}$ dan waktu pemanasan 5 menit. Solusi perlakuan terbaik yang didapat dari semua perlakuan disarankan pada program Design Expert 10 adalah suhu pemanasan $85^{\circ} \mathrm{C}$ dan waktu pemanasan 1 menit. produk sari tebu dengan suhu dan waktu pemanasan $85^{\circ} \mathrm{C}$ dan 1 menit menjadi produk dengan hasil yang optimum. Produk optimum tersebut mempunyai total sukrosa sebesar $12.86 \%$; kadar air sebesar $87.13 \%$; \%brix sebesar $12.87 \%$; gula reduksi sebesar $1.53 \%$ dan Total Plate Count sebesar $8.53 \times 10^{6} \mathrm{koloni} / \mathrm{ml}$.

\section{DAFTAR PUSTAKA}

Amalia Q. 2016. Optimasi Formula Daging Resutrukturisasi dengan Model Response Surface Methodology (Kajian Konsentrasi Gel Porang dan Karagenan serta Pewarna Angkak). Skripsi. Universitas Brawijaya. Malang

Andrade, I.M., Valichelli, I., Rocheto, A.C., Valadão, N.K., and Petrus R.R. 2014 Standardization of Pasteurized Sugarcane Juice. International Journal of Agriculture Innovations and Research. 2: 5, 794-797

Irawan, S.A., Sentosa G., dan Terip K.K. 2015. Pengaruh Perlakuan Fisik dan Lama Penyimpanan terhadap Mutu Minuman Ringan Nira Tebu. Jurnal Rekayasa Pangan dan Pertanian 3: 3, 343-353

Kuspratomo, A.D., Burhan, dan Fakhry. M. 2012. Pengaruh Varietas Tebu, Potongan dan Penundaan Giling Terhadap Nira Tebu. Agrointek. 6: 2, 123-132

Sankhla, S. 2011. A Study on Increasing the Shelf Life of Sugarcane Juice and Jaggery Using Hurdle Technology. University Rajendranagar. Thesis. Hyderabad

Singh, I., Solomon, S., Shrivastava, A.K., Singh, R.K and Singh, J. 2006. Post-harvest Quality Deterioration of Cane juice: Physio-biochemical Indicators. Sugar Technology 8: 2, 128-131.

Sivorsky, Z.E. 2007. Chemical and Functional Properties of Food Components 3rd ed. CRC Press. Boca Raton Florida.

Solomon, S. 2009. Post Harvest Deterioration of Sugarcane. Sugar Technology 11: 2, 109123.

Sunantyo, H.T. 2012. Pemakaian Batu Kapur dan Belerang sebagai Bahan Pembantu Pemurnian Nira untuk Meningkatkan Kualitas Gula Produk. Pasuruan. Pusat Penelitian Perkebunan Gula Indonesia.

Swaminathan, M. 1991. Essential of Foods and Nutrition. Vol 11. Bangalore Printing and Publishing Co.Ltd. Bangalore

Yunita, M., Hendrawan, Y., and Yulianingsih, R. 2015. Analisis Kuantitatif Mikrobiologi Pada Makanan Penerbangan (Aerofood ACS) Garuda Indonesia Berdasarkan TPC (Total Plate Count) Dengan Metode Pour Plate. Jurnal Keteknikan Pertanian Tropis dan Biosistem 3: 3, 237-248

Yusof, S., Shian, L.S., and Osman, A. 2000. Changes in Quality of Sugarcane Juice Upon Delayed Extraction and Storage. Food Chemistry 68: 395-401. 